\title{
Effectiveness of the Internet-based Versus Face-to-Face Interaction on Reduction of Tobacco use among Adults: A Systematic Review and Meta-Analysis
}

\section{Rajesh Kumar}

All India Institute of Medical Sciences (AlIMS)

\section{Ravi Kant}

All India Institute of Medical Sciences (AlIMS)

Poonam Yadav ( $\nabla$ dryadavpoonam257@gmail.com )

All India Institute of Medical Sciences (AlIMS)

\section{Tamar Rodney}

University of Maryland, Baltimore

\section{Mukesh Bairwa}

All India Institute of Medical Sciences (AlIMS)

\section{Research Article}

Keywords: Internet use, meta-analysis, Smoking cessation, systematic review, Tobacco.

Posted Date: March 24th, 2021

DOl: https://doi.org/10.21203/rs.3.rs-318627/v2

License: () (i) This work is licensed under a Creative Commons Attribution 4.0 International License. Read Full License 


\section{Abstract}

Literature reported the effectiveness of internet-based interventions over face-to-face interaction on tobacco quitting; however, limited sample size reinforces to integrate and analyze these studies' findings to reach a single conclusion. Therefore, we evaluated the effectiveness of the internet-based versus face-to-face interventions on reducing tobacco use with a systematic search through various electronic databases such as Medline, PsychInfo, PubMed, Embase, Cochrane Central Register of Controlled Trials (CENTRAL), ResearchGate, Google Scholar, and Academia. Reference lists of the eligible articles were also screened. Full-text articles were included as per eligibility criteria (PICO framework). A total of 13 studies were selected for meta-analysis, with 3852 and 3908 participants in intervention and control groups. Forest plot favours the intervention group at one month follow up for tobacco quitting (OR: $2.37, \mathrm{Cl}: 1.86-3.02, P-0.00001, \mathrm{I}^{2}=0 \%$ ), at three months (OR: $\left.1.88, \mathrm{Cl}: 1.48-2.40, P-0.00001, \mathrm{I}^{2}=42 \%\right)$ at six months (OR: 2.02, Cl: 1.64-2.50, P-0.00001, $\mathrm{I}^{2}=38 \%$ ) and at 1 year of follow-up (OR: 1.43, Cl: 1.18-1.74, $P-0.00001, \mathrm{I}^{2}=36 \%$ ). Internet and web-based interventions are highly useful in tobacco quitting at one month, three months, six months, and one year of follow-up compared to face-to-face interaction or no intervention, although the evidence level was moderate.

\section{Prospero Registration number- CRD42020214306}

\section{Introduction}

Tobacco consumption is the leading cause of avertible and premature deaths worldwide. ${ }^{[1,2]}$ Burden of tobacco-related disease is increasing in developed and developing countries as well. ${ }^{[3]}$ Interestingly, the deaths are declining in developed countries, and the burden is shifting to developing countries. ${ }^{[4]}$ However, tobacco consumption pattern varies across gender; male vs. female, domicile; rural vs. urban, regions, cultural practices, and family income. ${ }^{[5]}$ Men are more frequently (23\%) indulging in tobacco use than their counterparts (3\%). ${ }^{[6]}$ Quitting any form of smoking is challenging and involves physiological, psychological, and many other factors, including social and environmental milieu. ${ }^{[7,8]}$ to become successful. In the case of smoking cessation, the best use of positive and negative reinforcements helps alleviate the withdrawal symptoms, also the role of behavioral approaches in tobacco cessation cannot be denied. ${ }^{[9,10]}$

Over the years, many innovative forms of internet-based approaches have been tried to quit tobacco use globally. The use of health communication and internet-based interventions, ${ }^{[11,12]}$ tailored computerized programs, ${ }^{[13]}$ text messages, ${ }^{[14]}$ mobile or telephone, and WhatsApp for reminder or call, ${ }^{[15-18]}$ app-based intervention, ${ }^{[19]}$ chat-based instant messaging, ${ }^{[20]}$ video assistance using the website and mobile ${ }^{[8]}$ and use of social media, ${ }^{[21]}$ has been vividly used in recent decades to quit smoking among different age groups. Although there is ample research and data regarding the potential influence of the media, ${ }^{[22]}$ face to face health education, ${ }^{[23]}$ cognitive behavior therapy, ${ }^{[5,23]}$ motivational influences, ${ }^{[6]}$ nurses assisted counseling, ${ }^{[24,25]}$ on behavioral changes among smokers, there are scanty reports on the internet use or behavioral interventions. They are neither planned nor conducted rigorously to indicate firm evidence of any encouraging effects on health outcomes. ${ }^{[26]}$

Interestingly, internet use and other electronic platforms are abundantly present in this era and have almost become part and parcel of the health care system. ${ }^{[26]}$ A medical expert with just a computer device and internet access, and some necessary handling skills can reach many people and communicate inexpensively. Though the effectiveness of internet-based and face-to-face interventions on quitting smoking are very well reported in the literature, every study carries one or another limitation in methodology and limited sample size. Therefore, it is required to integrate and analyze these studies' findings to reach a single conclusion. This study was planned to assess the effectiveness of the internet versus face-to-face interactions on reducing tobacco use among adults.

Aim- To study the effectiveness of the internet versus face-to-face interventions on reducing tobacco use among adults.

\section{Results}

A systematic search was done by two reviewers independently. PRISMA flow chart displays all the steps followed in inclusion and exclusion of studies. ${ }^{[27]}$ (Figure 1) 
Characteristics of included studies, including the author's name with publication year, country, sample size, the mean age of participants, male to female ratio, baseline tobacco consumption, and follow-up period after the intervention, have been mentioned.

(Table 1).

\section{Risk of bias assessment}

Risk of bias has been assessed and created a risk of bias graph, and summary of included studies under the heads of selection bias, performance bias, detection bias, attrition bias, reporting bias, and any other bias observed across the studies. ${ }^{[28]}$ It depicts that there was no serious risk of bias across the studies (Figure 2). RevMan files were exported to the GRADE Profiler to assess the quality of studies and create a "Summary of Findings" table. ${ }^{[29]}$ (Table 2)

\section{Data analysis}

Tobacco quitting among participants has been analyzed at one, three, six, and twelve months of follow-up and presented in a forest plot (Figure 3). The Funnel plots have also been created to assess the publication bias across studies. It measures an effect estimate against its standard error for an outcome (Figure 4). 


\begin{tabular}{|c|c|c|c|c|c|c|c|}
\hline \multicolumn{8}{|c|}{ 3aseline characteristics of included studies } \\
\hline ear & Country & Interventions & $\begin{array}{l}\text { Sample size } \\
\text { Intervention/control } \\
\text { group }\end{array}$ & $\begin{array}{l}\text { Mean age of } \\
\text { participants } \\
\text { (years) }\end{array}$ & $\begin{array}{l}\text { Intervention/Control } \\
\text { group } \\
\text { Male/Female (\%) }\end{array}$ & $\begin{array}{ll}\text { Baseline } & \text { Cigarette } \\
\text { Consumption } & \end{array}$ & $\begin{array}{l}\text { Follow } \\
\text { up }\end{array}$ \\
\hline in & Norway & \begin{tabular}{l}
\multicolumn{1}{c}{ A digital multi- } \\
media \\
intervention consists \\
of more than 400 \\
contacts by email, \\
Web pages, \\
interactive voice \\
response, and short \\
message service \\
technology
\end{tabular} & $200 / 200$ smokers & $\begin{array}{l}\text { Intervention-35.9 } \pm 10.0 \\
\text { Control-36.4 } \pm 10.5\end{array}$ & $\begin{array}{l}\text { Intervention-49.2/50.8\% } \\
\text { Control-50.2/49.8 (\%) }\end{array}$ & $\begin{array}{l}\text { Intervention } 18.3 \pm 5.9 \\
\text { Control } 18.1 \pm 5.8 \text { cigs/day }\end{array}$ & $\begin{array}{l}1,3.6 \\
\text { and } 12 \\
\text { months }\end{array}$ \\
\hline \multirow[t]{4}{*}{$\begin{array}{l}\text { sn } \\
3^{[31]}\end{array}$} & Norway & $\begin{array}{l}\text { A digital multi- } \\
\text { media } \\
\text { intervention consists } \\
\text { of more than } 400 \\
\text { contacts by email, } \\
\text { Web pages, } \\
\text { interactive voice } \\
\text { response, and short } \\
\text { message service } \\
\text { technology without } \\
\text { nicotine therapy }\end{array}$ & $144 / 146$ smokers & $\begin{array}{l}\text { Intervention-39.5 } \pm 11 \\
\text { Control- } 39.7 \pm 10.8\end{array}$ & $\begin{array}{l}\text { Intervention-50/50 (\%) } \\
\text { Control- 50/50 (\%) }\end{array}$ & $\begin{array}{l}\text { Intervention: } 16.6 \pm 7.2 \\
\text { Control } 17.6 \pm 7 \text { cigs } / \text { day }\end{array}$ & $\begin{array}{l}1,3.6 \\
\text { and } 12 \\
\text { months }\end{array}$ \\
\hline & Australia & $\begin{array}{l}\text { A computer- } \\
\text { generated } \\
\text { photoaging } \\
\text { intervention with no } \\
\text { treatment group }\end{array}$ & $80 / 80$ smokers & $\begin{array}{l}\text { Intervention- } 24.2 \pm 4.1 \\
\text { Control- } 25.1 \pm 4.1\end{array}$ & $\begin{array}{l}\text { Intervention- } 31.3 / 68.7 \\
(\%) \\
\text { Control-43.8/56.2 (\%) }\end{array}$ & $\begin{array}{l}\text { Range- }<1-<21 \\
\text { Intervention-36.3\% } \\
\text { smoked } 11-20 \text { cigs/day } \\
\text { Control- } 33.8 \% \quad \text { smoked } \\
11-20 \text { cigs/day }\end{array}$ & $\begin{array}{l}6 \\
\text { months }\end{array}$ \\
\hline & $\begin{array}{l}\text { United } \\
\text { States }\end{array}$ & $\begin{array}{l}\text { Internet resources } \\
\text { for smoking } \\
\text { cessation compared } \\
\text { with written self- } \\
\text { help material }\end{array}$ & $85 / 86$ smokers & $\begin{array}{l}\text { Intervention-57.8 } \pm 5.2 \\
\text { Control-57.0 } \pm 5.3\end{array}$ & $\begin{array}{l}\text { Intervention-54/46 (\%) } \\
\text { Control-48/52 (\%) }\end{array}$ & $\begin{array}{l}\text { Range- }<10-<31 \\
\text { Intervention- } 48 \% \text { smoked } \\
11-20 \text { cigs/day } \\
\text { Control- } 44 \% \text { smoked } 11 \text { - } \\
20 \text { cigs/day }\end{array}$ & $\begin{array}{l}\text { One } \\
\text { year }\end{array}$ \\
\hline & $\begin{array}{l}\text { United } \\
\text { States }\end{array}$ & $\begin{array}{l}\text { Internet intervention } \\
\text { and tele-health } \\
\text { medication clinic } \\
\text { combined with a } \\
\text { tele-health } \\
\text { medication clinic for } \\
\text { nicotine } \\
\text { replacement therapy }\end{array}$ & 205/203 smokers & $\begin{array}{l}\text { Intervention- } \\
43.3 \pm 13.6 \\
\text { Control- } \\
42.6 \pm 14.3\end{array}$ & $\begin{array}{l}\text { Intervention- } \\
85 / 15(\%) \\
\text { Control-84/16 (\%) }\end{array}$ & $\begin{array}{l}\text { Intervention- } \\
\text { Control-15.7 } \pm 8.8 \\
14.6 \pm 8.5\end{array}$ & $\begin{array}{l}3 \\
\text { months } \\
\text { and } 12 \\
\text { months }\end{array}$ \\
\hline i, & Netherlands & $\begin{array}{l}\text { Web-based } \\
\text { computer-tailored } \\
\text { programs }\end{array}$ & $190 / 202$ & $\begin{array}{l}\text { Intervention- } 40.75 \pm \\
11.48 \\
\text { Control- } 40.68 \pm 11.81 \\
\end{array}$ & $\begin{array}{l}\begin{array}{l}\text { Intervention- } 36.7 / 63.3 \\
(\%)\end{array} \\
\text { Control- } 40.1 / 59.9(\%) \\
\end{array}$ & $\begin{array}{l}\text { Intervention- } \\
\pm 9.36) \\
\text { Control- } 19.85 \pm 8.39 \\
\end{array}$ & $\begin{array}{l}\text { Twelve } \\
\text { months }\end{array}$ \\
\hline 1, & $\begin{array}{l}\text { United } \\
\text { States }\end{array}$ & $\begin{array}{l}\text { Web site which } \\
\text { provided } \\
\text { information on } \\
\text { smoking cessation } \\
\text { as well as support }\end{array}$ & $140 / 144$ smokers & $\begin{array}{l}\text { Intervention- } 40.6 \pm 12.4 \\
\text { Control-41.0 } 11.8\end{array}$ & $\begin{array}{l}\text { Intervention-45/55 (\%) } \\
\text { Control-45.1/54.9 (\%) }\end{array}$ & $\begin{array}{l}\text { Intervention- } 21.1 \pm 9.5 \\
\text { Control- } \\
1 . \pm 10.2\end{array}$ & $\begin{array}{l}\text { Six } \\
\text { months }\end{array}$ \\
\hline $\mathrm{e}$ & $\begin{array}{l}\text { United } \\
\text { States }\end{array}$ & $\begin{array}{l}\text { Personalized } \\
\text { smoking } \\
\text { cessation through an } \\
\text { online life magazine } \\
\end{array}$ & $257 / 260$ smokers & $\begin{array}{l}\text { Intervention- } 20.1 \pm 1.6 \\
\text { Control-19.8 } 1.6\end{array}$ & $\begin{array}{l}\text { Intervention-24.6/75.4 (\%) } \\
\text { Control-29.6/70.4 (\%) }\end{array}$ & $\begin{array}{l}\text { Intervention-3.8 } \pm \text { 4.7) } \\
\text { Control- } 4.2 \pm 5.0\end{array}$ & $\begin{array}{l}\text { Thirty } \\
\text { weeks }\end{array}$ \\
\hline sll, & Korea & $\begin{array}{l}\text { Internet self-help } \\
\text { smoking cessation } \\
\text { programme }\end{array}$ & 272/315 Smokers & $\begin{array}{l}\text { Total } \\
35 \text { years (mean) }\end{array}$ & Total- 12/88 (\%) & $\begin{array}{lll}\text { Total- } & 14 & \text { cigs/smoking } \\
\text { day } & & \end{array}$ & $\begin{array}{l}\text { Twelve } \\
\text { months }\end{array}$ \\
\hline . & Netherlands & $\begin{array}{lr}\text { An } & \text { internet } \\
\text { delivered } & \text { computer } \\
\text { tailored } & \text { lifestyle } \\
\text { intervention } & \end{array}$ & $1080 / 1079$ smokers & 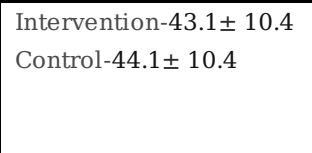 & $\begin{array}{l}\text { Intervention-46/54 (\%) } \\
\text { Control-47/53 (\%) }\end{array}$ & NA & $\begin{array}{l}\text { One } \\
\text { month }\end{array}$ \\
\hline
\end{tabular}




\begin{tabular}{|c|c|c|c|c|c|c|}
\hline Denmark & $\begin{array}{l}\text { Interactive, } \\
\text { individual advice, } \\
\text { newly developed by } \\
\text { the Research Centre }\end{array}$ & $476 / 442$ smokers & $\begin{array}{l}\text { Intervention }-49.63 \pm 16 \\
\text { Control- } 46.97 \pm 17\end{array}$ & $\begin{array}{l}\text { Intervention-36.8/63.2 (\%) } \\
\text { Control-36.6/63.4 (\%) }\end{array}$ & $\begin{array}{l}\text { Intervention }-18.12 \pm 10 \\
\text { Control- } 16.25 \pm 8\end{array}$ & $\begin{array}{l}\text { Twelve } \\
\text { months }\end{array}$ \\
\hline Netherlands & $\begin{array}{l}\text { A multiple computer- } \\
\text { tailored smoking } \\
\text { cessation } \\
\text { intervention through } \\
\text { the Internet }\end{array}$ & $552 / 571$ & $\begin{array}{l}\text { Intervention- } 48.4 \pm 12.2 \\
\text { Control- } 48.8 \pm 12.3\end{array}$ & $\begin{array}{l}\text { Intervention- } 45.8 / 54.2 \\
(\%) \\
\text { Control-49.4/ } 50.6(\%)\end{array}$ & $\begin{array}{l}\text { Intervention }-20.8 \pm 13.7 \\
\text { Control- } 20.4 \pm 11\end{array}$ & $\begin{array}{l}1 \\
\text { month } \\
\text { and } 6 \\
\text { months }\end{array}$ \\
\hline $\begin{array}{l}\text { United } \\
\text { States }\end{array}$ & $\begin{array}{lr}\text { A video-based } \\
\text { internet site that } \\
\text { presented current } \\
\text { strategies } \\
\text { smoking cessation } \\
\text { and motivational } \\
\text { materials }\end{array}$ & $171 / 180$ smokers & $\begin{array}{l}\text { Intervention- } \\
\text { Control-18-70 years } \\
\text { (range) }\end{array}$ & $\begin{array}{l}\text { Intervention-46.8/53.2 (\%) } \\
\text { Control-8.9/50.6 (\%) }\end{array}$ & $\begin{array}{l}\text { Range }<16->31 ; \quad 32.3 \% \\
\text { smoked } 16-20 \text { cigs/day }\end{array}$ & $\begin{array}{l}1 \\
\text { month }\end{array}$ \\
\hline
\end{tabular}

Table 2 Summary of findings Table

\begin{tabular}{|c|c|c|c|c|c|}
\hline \multirow[t]{2}{*}{ Outcomes } & \multicolumn{2}{|c|}{ Anticipated absolute effects* ${ }^{*}(95 \% \mathrm{CI})$} & \multirow{2}{*}{$\begin{array}{l}\text { Relative } \\
\text { effect } \\
(95 \% \text { CI })\end{array}$} & \multirow{2}{*}{$\begin{array}{c}\text { № of } \\
\text { participants } \\
\text { (studies) }\end{array}$} & \multirow{2}{*}{$\begin{array}{l}\text { Certainty of the } \\
\text { evidence } \\
\text { (GRADE) }\end{array}$} \\
\hline & $\begin{array}{l}\text { Events in control } \\
\text { group }\end{array}$ & $\begin{array}{c}\text { Events in Internet intervention } \\
\text { group }\end{array}$ & & & \\
\hline $\begin{array}{l}\text { Tobacco quit at } 1 \text { month } \\
\text { follow up }\end{array}$ & 105 per 1,000 & $\begin{array}{l}217 \text { per } 1,000 \\
(179 \text { to } 261)\end{array}$ & $\begin{array}{l}\text { OR } 2.37 \\
(1.86 \text { to } \\
3.02)\end{array}$ & $\begin{array}{c}2531 \\
\text { (5 RCTs) }\end{array}$ & $\begin{array}{l}\oplus \oplus \oplus \bigcirc \\
\text { MODERATE }\end{array}$ \\
\hline $\begin{array}{l}\text { Tobacco quit at } 3 \text { months } \\
\text { follow up }\end{array}$ & 164 per 1,000 & $\begin{array}{l}269 \text { per } 1,000 \\
(225 \text { to } 320)\end{array}$ & $\begin{array}{l}\text { OR } 1.88 \\
(1.48 \text { to } \\
2.40)\end{array}$ & $\begin{array}{c}1733 \\
(5 \text { RCTs) }\end{array}$ & $\begin{array}{c}\oplus \oplus \bigoplus \bigcirc \\
\text { MODERATE b }\end{array}$ \\
\hline $\begin{array}{l}\text { Tobacco quit at } 6 \text { months } \\
\text { follow up }\end{array}$ & 125 per 1,000 & $\begin{array}{l}224 \text { per } 1,000 \\
(190 \text { to } 263)\end{array}$ & $\begin{array}{l}\text { OR } 2.02 \\
(1.64 \text { to } \\
2.50)\end{array}$ & $\begin{array}{c}2774 \\
(6 \mathrm{RCTs})\end{array}$ & $\begin{array}{c}\oplus \oplus \oplus \bigcirc \\
\text { MODERATE }^{\text {a }}\end{array}$ \\
\hline $\begin{array}{l}\text { Tobacco quit at one year } \\
\text { follow up }\end{array}$ & 187 per 1,000 & $\begin{array}{l}248 \text { per } 1,000 \\
(214 \text { to } 286)\end{array}$ & $\begin{array}{l}\text { OR } 1.43 \\
(1.18 \text { to } \\
1.74)\end{array}$ & $\begin{array}{c}2757 \\
\text { (6 RCTs) }\end{array}$ & $\underset{\text { MODERATE }}{\oplus \oplus \bigoplus \bigcirc}$ \\
\hline
\end{tabular}

\section{a. Wide confidence interval}

b. Heterogeneity

\section{Tobacco quitting outcome}

A total of 13 articles were found suitable for meta-analysis, with 3852 and 3908 participants in intervention and control groups. [30${ }^{42]}$ All studies revealed data with a sample size ranging from $160^{[32]}$ to $2159^{[39]}$. Baseline characteristics of included studies have been described in table 1. All studies have nearly equal male and female participants. Only two studies Lawrence et al. and Pisinger et al. had majority of female participants (Intervention-75.4 \% / Control-70.4 \%) and (Intervention-63.2 \% Control-63.4 \%) respectively. ${ }^{[37,40]}$ Calhoun et al. had the majority of male participants in the intervention (85\%) and control group (84 \%). ${ }^{[34]}$

Two studies measured the outcome at four steps: one, three, six months, and one year. [30, 312] Two studies followed up the participants only for one month. ${ }^{[39,42]}$ Two studies measured the outcome at six months only. ${ }^{[32,36]}$ Calhoun et al. measured the outcome at three months and twelve months of internet intervention and telehealth medication clinic unite with a telehealth medication clinic for nicotine replacement therapy. ${ }^{[34]}$ Even four studies assessed the outcome of tobacco use at one year of different web or internet-based intervention. ${ }^{[33,35,38.40]}$

Subgroup analysis with tobacco quitting outcomes at one, three, six months, and one-year follow-up further lowers the heterogeneity across studies. Sensitivity analysis was done to find the better result with a random effect model. We observed 
similar results with the random effect model also. Pike $\mathrm{KJ}$ et al. have been removed from the analysis due to the vast difference in the number of participants in both groups, creating heterogeneity. ${ }^{[43]}$

The Forest plot favors the intervention group (OR: 2.37, Cl: 1.86-3.02, P-0.00001, $\mathrm{I}^{2}=0 \%$ ) in comparison to the control group for quitting tobacco at a one-month follow-up (Figure 3).

The Forest plot also favors the intervention group compared to the control group (OR: $1.88, \mathrm{Cl}: 1.48-2.40, \mathrm{P}-0.00001, \mathrm{I}^{2}=42 \%$ ) for quitting tobacco at three months follow up (Figure 3).

The Forest plot also favors the intervention group compared to the control group (OR: 2.02, Cl: 1.64-2.50, P-0.00001, $\mathrm{I}^{2}=38 \%$ ) for quitting tobacco at six months follow up (Figure 3).

The Forest plot also favors the intervention group compared to the control group (OR: 1.43, Cl: 1.18-1.74, P-0.00001, $\mathrm{I}^{2}=36 \%$ ) for quitting tobacco at one year follow up (Figure 3).

The forest plot suggests significantly higher tobacco quitting events in the internet intervention group at one, three, six, and twelve months of participants' follow-up with moderate heterogeneity across the studies.

\section{Discussion}

Over the year, many innovative forms of internet-based approaches ${ }^{[11]}$ tailored computerized programs, ${ }^{[13]}$ text messages, ${ }^{[14]}$ mobile or telephone, and WhatsApp for reminder or call, ${ }^{[15-18]}$ app-based intervention, ${ }^{[19]}$ chat-based instant messaging, ${ }^{[20]}$ video assistance using the website and mobile ${ }^{[8]}$ and use of social media, ${ }^{[21]}$ have been practiced commonly to quit tobacco in different age group population. Although, various methodological issues reduce the ability to estimate the effects of internet-based approaches.

This study evaluated the impact of the internet approaches versus face-to-face interaction on reducing tobacco use in the adult population. Results suggestive of significantly higher tobacco quitting events in the internet intervention group than the control group at one month, three months, six months, and one year of follow-up of participants with moderate heterogeneity across the studies. Happy ending, a digital multi-media smoking cessation intervention consists of more than 400 contacts through emails, interactive voice responses, Web pages, and short message service compared with self-help booklet, reported higher point abstinence rates in the treatment group in the long-term effect of the intervention. [30, 31]

A written list of internet resources for smoking cessation was found more helpful than written self-help material to quit smoking for a long-term period of one year. ${ }^{[33]}$ Internet-based self-help smoking cessation program, interactive, individual advice, multiple computer-tailored smoking cessation internet interventions, and a video-based internet site presented strategies for motivational materials and smoking cessation found no effect at six months of intervention but the significant effect at 12 months of follow up. $[38,40,41,42]$ Personalized smoking cessation through an online life magazine in the young population enhanced smoking cessation at the end of 12 months. ${ }^{[37]}$

Internet use and telehealth medication clinic combined with a telehealth medication clinic for nicotine replacement therapy reported no significant difference (17\% vs. $12 \%$ ) in comparison to clinical-based smoking cessation after three months of intervention. ${ }^{\text {[4] }}$ However, Burford $\mathrm{O}$ et al. compared a computer-generated photoaging intervention with no treatment group and reported a higher (27.5\%) incidence of smoking quit than the control group (6.3\%) at six months follow up. ${ }^{\left[{ }^{32]}\right.}$ Rabius $V$ et al. reported the follow-up response rate as $38 \%$, and Feil EG et al. achieved $50 \%$ responses from participants with monetary incentives. ${ }^{[44,45]}$ Findings were also reinforced by the researchers that the participants' loss inevitably influences research on the internet for health purposes. ${ }^{[46,}$

${ }^{47]}$ After the quit attempts, web-based interventions could be more effective in preventing relapse in the long term, which requires adherence to the intervention for its effectiveness. ${ }^{[35]}$

Additionally, an approach to a website supporting smoking abstinence is not related to smoking cessation. ${ }^{[36]}$ Civljak M et al. reported the strong effect of uniting tailored materials with nicotine replacement therapy on tobacco cessation and a significant 
positive impact of tailored materials among pre-contemplators. ${ }^{[48]}$ Previous studies compared the tailored to untailored web-based intervention; few studies have observed that tailored web-based intervention is equally efficacious to untailored intervention [49-54], while others have found the tailored intervention to be better in comparison to untailored one. $[39,55,56]$

The internet services should be based on their preference and easily accessible to those who want to quit smoking and seek related information through the internet and utilize the internet services. ${ }^{[57]}$ Presently, internet interventions' incremental cost is less than other modalities, facilitating and evaluating online programs for effectiveness. ${ }^{[58]}$ Online interventions also can access smokers

and support them in quitting tobacco, which is also firmly associated with the total and physical quality of life among adults. ${ }^{\text {[58, 59] }}$ Despite variations in trials, this meta-analysis adds to the evidence for the promising approach of the internet-based intervention in modifying behavior, reducing tobacco use, and enhancing positive health practices among adults.

\section{Strength and limitations}

Subgroup analysis explored and discussed the possibility of tobacco quitting in the adult population at different time points. Sensitivity analysis strengthened the evidence by exploring possible alternate findings.

Although there was lack of uniformity of internet-based approaches in included trials, they had different internet approaches, which have also been discussed. (Table 1) The risk of included bias in the individual trial also contributed towards the limitation of metaanalysis. (Figure 2)

\section{Conclusion}

This meta-analysis pooled the data of randomized controlled trials with limited sample size. It winded up that internet use is highly effective in tobacco quitting at one, three, six, and twelve months of follow-up of participants compared to face-to-face intervention or no intervention with moderate heterogeneity across the studies a moderate level of evidence to support the findings. Further studies are required to explore internet interventions' durable adherence among the adult population who their spared maximum time with the internet in any form. Additionally, limited availability of trials in developing countries, arising need for research of internet use in developing countries to quit tobacco. Findings provide evidence to policymakers to utilize the internet as an effective instrument for tobacco control in their countries.

\section{Methods}

\section{Data sources and search strategy}

The electronic databases, such as Medline, Embase, PsychInfo, Cochrane Central Register of Controlled Trials (CENTRAL), PubMed, Google Scholar, Academia, and ResearchGate, were explored. Reference lists of the selected articles were also screened. All relevant studies available on the topic were included irrespective of time duration. The systematic search was restricted to studies published in the English language. The keywords were "smoker or smokers OR smoking," "tobacco" OR cigarette OR nicotine OR smoking cessation OR "tobacco consumption OR cessation, OR abstain* OR quit^ OR stop* OR computer OR computer-aided design, OR internet, OR computer, OR networks, OR media, OR cellular phone OR mobile, OR text OR message* OR SMS, OR web, OR electronic mail OR Chat, OR video recording.

\section{Eligibility criteria}

\section{PICO Framework}

\section{Participants}

Inclusion: Adults aged more than 18 years use the internet or face-to-face interventions to reduce or quit tobacco use. No ethnicity restrictions were applied.

Exclusion: Cochrane studies that compare the internet to face-to-face interventions with other interventions. 


\section{Intervention}

Internet interventions (Phone, mobile, WhatsApp, Facebook, Online network group, Online Support group, text messaging, other internet media)

\section{Comparator}

Face-to-face interventions or no intervention in the comparator group.

Face-to-face interventions include counseling, cognitive behavior therapy, or health education forms with control or routine care.

\section{Outcome}

Post-intervention tobacco quitting - number of participants quitting tobacco after the intervention (internet use)

\section{Study design}

Randomized controlled trials

\section{Time frame}

No restriction to the time frame was applied.

\section{Screening of eligible studies}

A systematic search was done by two reviewers independently. After searching, studies were screened with titles and abstracts of respective studies. All selected studies were imported to Rayyan (https://rayyan.qcri.org), a free web-based software. ${ }^{[60]}$ Two reviewers screened the full text of articles based on eligibility criteria determined as per review protocol. Any relevant discrepancy has been resolved by consensus with the help of a third reviewer. We adhered to the guidelines of Preferred Reporting Items for Systematic Review and Meta-Analysis (PRISMA) 2009. ${ }^{28]}$ (Additional File. 1)

\section{Data extraction}

Two reviewers extracted the data from the full text of eligible studies. Corresponding authors of included studies were contacted for the relevant data. Data excel sheet was prepared to note the characteristics of selected studies. It includes the author's name with publication year, country, sample size, participants' mean age, male to female ratio, baseline tobacco consumption, and follow-up period after the intervention (Table 1).

Eligible studies were exported to RevMan software for data analysis. Forest plots have been created to present the results with Odds ratio (OR), confidence interval $(\mathrm{Cl})$, and effect size.

\section{Risk of bias assessment}

Two reviewers independently assessed the quality of included studies. Risk of bias graph and summary has been created in Review Manager software 5.4 version under the heads of Random sequence generation (selection bias), Blinding of participants and personnel (performance bias), Allocation concealment (selection bias), Blinding of outcome assessment, (detection bias), Incomplete outcome data (attrition bias), Selective reporting (reporting bias), and Other bias (Figure 2). [29]

The GRADE approach was also followed to explore the quality of evidence on high, moderate, and low levels. ${ }^{[30]}$ RevMan files were exported to the GRADE Profiler to assess the quality of studies and create a "Summary of Findings" table (Table 2).

\section{Data analysis}

Review Manager software 5.4 version was used for meta-analysis. ${ }^{[29]}$ The fixed-effects model and effect measures were calculated as the OR with p-value $<0.05$ considered statistically significant. $\left.\right|^{2}$ statistics with 25,50 , and $75 \%$ were measured to compute statistical heterogeneity in low, moderate, and high grades. The tabulated data presented in a forest plot (Figure 3 ). 
Funnel plots have also been created to assess the publication bias across studies. It measures an effect estimate against its standard error for an outcome (Figure 4).

Tobacco quitting among participants has been analyzed at one, three, six, and twelve months of follow-up and presented in a forest plot (Figure 3).

\section{Declarations}

\section{Acknowledgment: None}

\section{Author's Contributions}

Study conception/design: Y. P., K. R.

Data extraction, analysis, and interpretation: Y. P., K. R., K. R., R. T., R. T., B. M.

Drafting Manuscript: Y. P.

Revising manuscript: Y. P., K. R., K. R., R. T., B. M.

Approval of a final version of the manuscript for publication: Y.P., K. R., K. R., R. T., B. M.

\section{Competing interests}

The authors declare no competing interests

\section{References}

1. Peto R. et al. Mortality from smoking worldwide. British medical bulletin.52,12-21 (1996).

2. Lopez AD. Video Q\&A: Tobacco-related mortality: past, present, and future. An interview with Alan Lopez. BMC Medicine. 12, 162. https://doi.org/10.1186/s12916-014-0162-x (2004).

3. Collishaw NE. The millennium development goals and tobacco control. Glob Health Promot. Mar. 17, (1 Suppl),51-9 (2010).

4. World Health Organisation (WHO). WHOReport on the Global Tobacco Epidemic, 2008: The MPOWER Package. Switzerland: https://www.who.int/tobacco/mpower/mpower_report_full_2008.pdf (2008).

5. Ng M. et al. Smoking Prevalence and Cigarette Consumption in 187 Countries, 1980-2012. 311, 183-92 (2014).

6. Grills NJ, Singh R, Singh R, Martin BC. Tobacco Usage in Uttarakhand: A Dangerous Combination of High Prevalence, Widespread Ignorance, and Resistance to Quitting. Biomed Res Int. 2015,132120 (2015).

7. Martínez-Vispo C. et al. Cognitive-behavioral treatment with behavioral activation for smoking cessation: Randomized controlled trial. PloS one. 14, e0214252 (2019).

8. Laland KN, Rendell L. Social Learning: Theory. In: Choe JC, editor. Encyclopedia of Animal Behavior (Second Edition). Oxford: Academic Press. 380-6. http://www.sciencedirect.com/science/article/pii/B9780128132517000572 (2010).

9. Baker TB, Brandon TH, Chassin L. Motivational Influences on Cigarette Smoking. Annual Review of Psychology. 55, 463-91 (2004).

10. Audrain-McGovern J, Rodriguez D, Rodgers K, Cuevas J. Declining alternative reinforcers link depression to young adult smoking. Addiction. 106, 178-87 (2011).

11. Cassell MM, Jackson C, Cheuvront B. Health communication on the internet: an effective channel for health behavior change? Journal of health communication. 3,71-9 (1998).

12. Takahashi Y. et al. A new smoking cessation programme using the internet. Tobacco control. 8, 109-10 (1999).

13. Etter JF, Perneger T V. Effectiveness of a computer-tailored smoking cessation program: a randomized trial. Archives of internal medicine.161,2596-601 (2001). 
14. Liao Y. et al. effectiveness of a text-messaging-based smoking cessation intervention ("Happy Quit") for smoking cessation in China: A randomized controlled trial. PLoS Medicine.15,1-18 (2018).

15. Durmaz S. et al. WhatsApp embedded in routine service delivery for smoking cessation: effects on abstinence rates in a randomized controlled study. BMC Public Health. 19, 387 (2019).

16. Cheung YTD. et al. Using WhatsApp and Facebook Online Social Groups for Smoking Relapse Prevention for Recent Quitters: A Pilot Pragmatic Cluster Randomized Controlled Trial. Journal of medical Internet research.17, (2015).

17. Zhu S-H. et al. evidence of real-world effectiveness of a telephone quitline for smokers. N Engl J Med. 347, 1087-93 (2002).

18. Whittaker R. et al. Mobile phone text messaging and app-based interventions for smoking cessation. Cochrane Database Syst Rev. 10, (10):CD006611 (2019).

19. Wang MP. et al. Chat-based instant messaging support integrated with brief interventions for smoking cessation: a community-based, pragmatic, cluster-randomised controlled trial. The Lancet Digital Health.1,e183-92 (2019).

20. Naslund JA. et al. Systematic review of social media interventions for smoking cessation. Addictive behaviors. 73, 81-93 (2017).

21. Langley TE, McNeill A, Lewis S, Szatkowski L, Quinn C. The impact of media campaigns on smoking cessation activity: a structural vector autoregression analysis. 107, 2043-50 (2012).

22. Reddy UK. Et al. Effectiveness of health education and behavioral intervention for tobacco de-addiction among degree students: A clinical trial. Journal of International Society of Preventive \& Community Dentistry. 5, S93-100 (2015).

23. Hollis JF, Lichtenstein E, Vogt TM, Stevens VJ, Biglan A. Nurse-assisted counseling for smokers in primary care. Annals of internal medicine. 118, 521-5. (1993)

24. Bessell TL. Et al. Do Internet interventions for consumers cause more harm than good? A systematic Health Expect. 5,28-37 (2002).

25. Haokip HR, Kumar R, Singh Rawat V, Sharma SK. Efficacy of standard nicotine replacement therapy (NRT) versus videoassisted nurse-led NRT on tobacco cessation: A randomized controlled pilot trial. Clinical Epidemiology and Global Health. 9, 141-6 (2021).

26. Mansoor I. The medical uses of internet and how to stay current with internet. J Family Community Med. 9, 63-4 (2002).

27. Moher D, Liberati A, Tetzlaff J, Altman DG, Group TP. Preferred reporting items for systematic reviews and meta-analyses: The PRISMA statement. PLoS Med. 6, e1000097 (2009).

28. Review Manager. 53rd ed. Copenhagen: The Nordic Cochrane Centre, The Cochrane Collaboration; (2014).

29. GRADEpro: GRADEpro. Hamilton: McMaster University (2014).

30. Brendryen H, Kraft P. Happy ending: a randomized controlled trial of a digital multi-media smoking cessation intervention. 103, (3):478-84; discussion 485-6 (2008).

31. Brendryen H, Drozd F, Kraft P. A digital smoking cessation program delivered through internet and cell phone without nicotine replacement (happy ending): randomized controlled trial. J Med Internet Res. 10, (5):e51 (2008).

32. Burford O, Jiwa M, Carter O, Parsons R, Hendrie D. Internet-based photoaging within Australian pharmacies to promote smoking cessation: randomized controlled trial. J Med Internet Res. 15, (3):e64. (2013).

33. Clark MM. et al. Effectiveness of smoking cessation self-help materials in a lung cancer screening population. Lung Cancer. 44, (1):13-21 (2004).

34. Calhoun PS. et al. Comparative Effectiveness of an Internet-Based Smoking Cessation Intervention Versus Clinic-Based Specialty Care for Veterans. J Subst Abuse Treat. 69,19-27 (2016).

35. Elfeddali I, Bolman C, Candel MJ, Wiers RW, de Vries H. Preventing smoking relapse via Web-based computer-tailored feedback: a randomized controlled trial. J Med Internet Res. 14, e109 (2012).

36. Japuntich SJ. Et al. Smoking cessation via the internet: a randomized clinical trial of an internet intervention as adjuvant treatment in a smoking cessation intervention. Nicotine Tob Res. 8 Suppl 1, S59-67 (2006).

37. An LC. Et al. The RealU online cessation intervention for college smokers: a randomized controlled trial. Prev Med. 47, 194-9 (2008). 
38. McDonnell DD, Kazinets G, Lee HJ, Moskowitz JM. An internet-based smoking cessation program for Korean Americans: results from a randomized controlled trial. Nicotine Tob Res. 13, (5)336-43 (2011).

39. Oenema A, Brug J, Dijkstra A, de Weerdt I, de Vries H. Efficacy and use of an internet-delivered computer-tailored lifestyle intervention, targeting saturated fat intake, physical activity and smoking cessation: a randomized controlled trial. Ann Behav Med. 35,(2):125-35 (2008).

40. Pisinger C, Jørgensen MM, Møller NE, Døssing M, Jørgensen T. A cluster randomized trial in general practice with referral to a group-based or an Internet-based smoking cessation programme. J Public Health (Oxf). 32, (1):62-70 (2010).

41. Smit ES, de Vries H, Hoving C. Effectiveness of a Web-based multiple tailored smoking cessation program: a randomized controlled trial among Dutch adult smokers. J Med Internet Res. 14, (3):e82 (2012).

42. Swartz LH, Noell JW, Schroeder SW, Ary DV. A randomised control study of a fully automated internet based smoking cessation programme. Tob Control.15, (1):7-12 (2006).

43. Pike KJ, Rabius V, McAlister A, Geiger A. American Cancer Society's QuitLink: randomized trial of Internet assistance. Nicotine Tob Res. 9, (3):415-20 (2007).

44. Rabius V, Pike KJ, Wiatrek D, McAlister AL. Comparing internet assistance for smoking cessation: 13-month follow-up of a sixarm randomized controlled trial. J Med Internet Res. 10, (5): e45 (2008).

45. Feil EG, Noell J, Lichtenstein E, Boles SM, McKay HG. Evaluation of an Internet-based smoking cessation program: lessons learned from a pilot study. Nicotine Tob Res. 5, (2):189-94 (2003).

46. Eysenbach G. Issues in evaluating health websites in an Internet-based randomized controlled trial. J Med Internet Res. 4, (3): E17 (2002).

47. Eysenbach G. The law of attrition. J Med Internet Res. 7, (1): e11 (2005).

48. Civljak M, Sheikh A, Stead LF, Car J. Internet-based interventions for smoking cessation. Cochrane Database Syst Rev. 8 , CD007078 (2010).

49. McKay HG, Danaher BG, Seeley JR, Lichtenstein E, Gau JM. Comparing two web-based smoking cessation programs: randomized controlled trial. J Med Internet Res. 10, (5):e40 (2008).

50. Rabius V, Pike KJ, Wiatrek D, McAlister AL. Comparing internet assistance for smoking cessation: 13-month follow-up of a sixarm randomized controlled trial. J Med Internet Res.10, (5):e45 (2008).

51. Stoddard JL, Augustson EM, Moser RP. Effect of adding a virtual community (bulletin board) to smokefree. gov: Randomized controlled trial. J Med Internet Res. 2008;10:e53.

52. Etter JF. Comparing computer-tailored, internet-based smoking cessation counseling reports with generic, untailored reports: A randomized trial. J Health Commun. 14, 646-57 (2009).

53. Muñoz RF. et al. Toward evidence-based Internet interventions: A Spanish/English Web site for international smoking cessation trials. Nicotine Tob Res.8, 77-87 (2006).

54. Muñoz RF, Barrera AZ, Delucchi K, Penilla C, Torres LD, Pérez-Stable EJ. International Spanish/English Internet smoking cessation trial yields 20\% abstinence rates at 1 year. Nicotine Tob Res.11, 1025-34 (2009).

55. Strecher VJ. et al. Web-based smoking-cessation programs: Results of a randomized trial. Am J Prev Med. 34, 373-81 (2008).

56. Strecher VJ, Shiffman S, West R. Randomized controlled trial of a web-based computer-tailored smoking cessation program as a supplement to nicotine patch therapy. 100, 682-8 (2005).

57. Fox S. Pew Internet. Washington, DC: Pew Internet \& American Life Project. Online health search 2006 URL: http://www.pewinternet.org/ /media/Files/Reports/2006/PIP_Online_Health_2006.pdf. (2006).

58. Meenan, R. T. et al. Development and implementation cost analysis of telephone- and internet-based interventions for the maintenance of weight loss. International Journal of interventions. Annals of Behavioral Medicine. 38, 18-27 (2009).

59. Bloom EL. et al. Quality of life after quitting smoking and initiating aerobic exercise. Psychol Health Med. 22, (9):11271135 (2017).

60. Ouzzani M, Hammady H, Fedorowicz Z, Elmagarmid A. Rayyan - a web and mobile app for systematic reviews. Sys Rev. 5, 210 (2016). 
Flow chart (PRISMA)

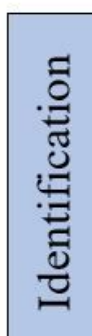

Number of Records identified
through database searching
$(\mathrm{n}=297)$

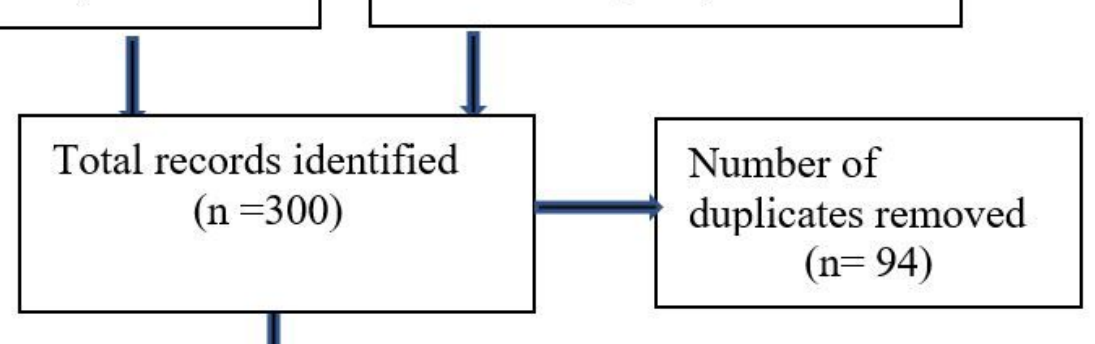

Additional records identified through other sources

$$
(n=3)
$$
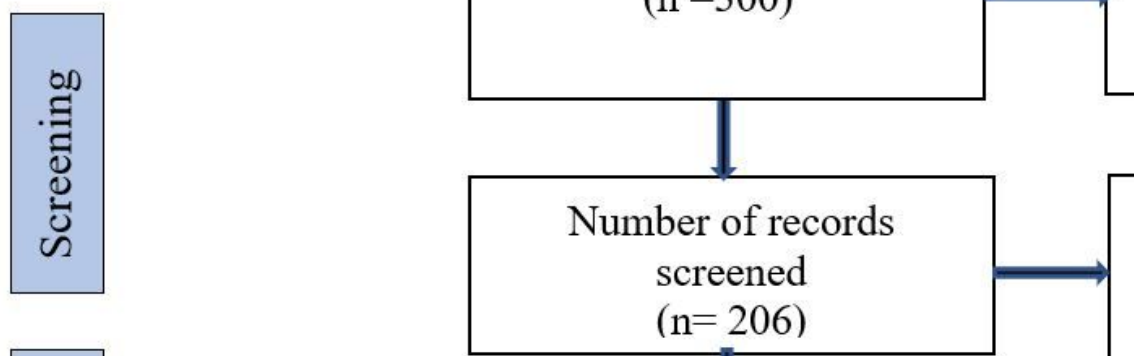

Number of records excluded
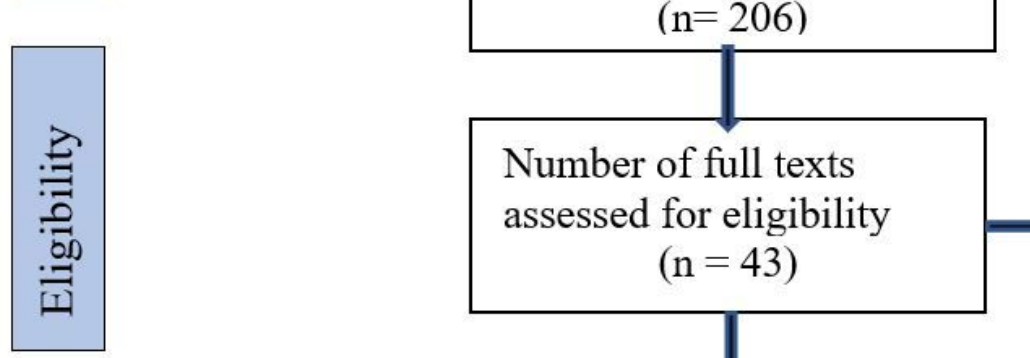

$$
\begin{aligned}
& \text { Number of full texts } \\
& \text { assessed for eligibility } \\
& (\mathrm{n}=43)
\end{aligned}
$$
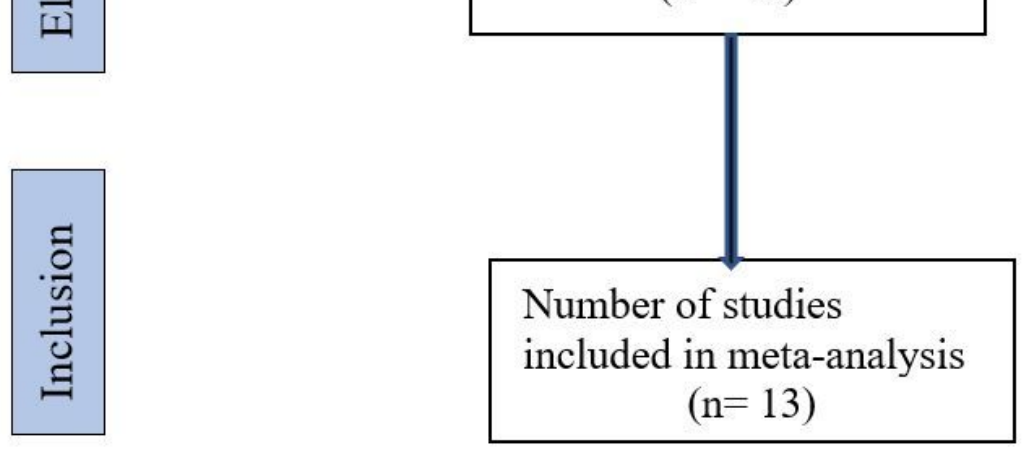

$$
(\mathrm{n}=163)
$$

Number of full text articles excluded with reasons

$(\mathrm{n}=30)$

Different Study design $=5$

Included adolescent age group- 7

Only protocol $=2$

Non comparable control $=11$

Different outcomes $=5$

Figure 1

Flow chart (PRISMA) 


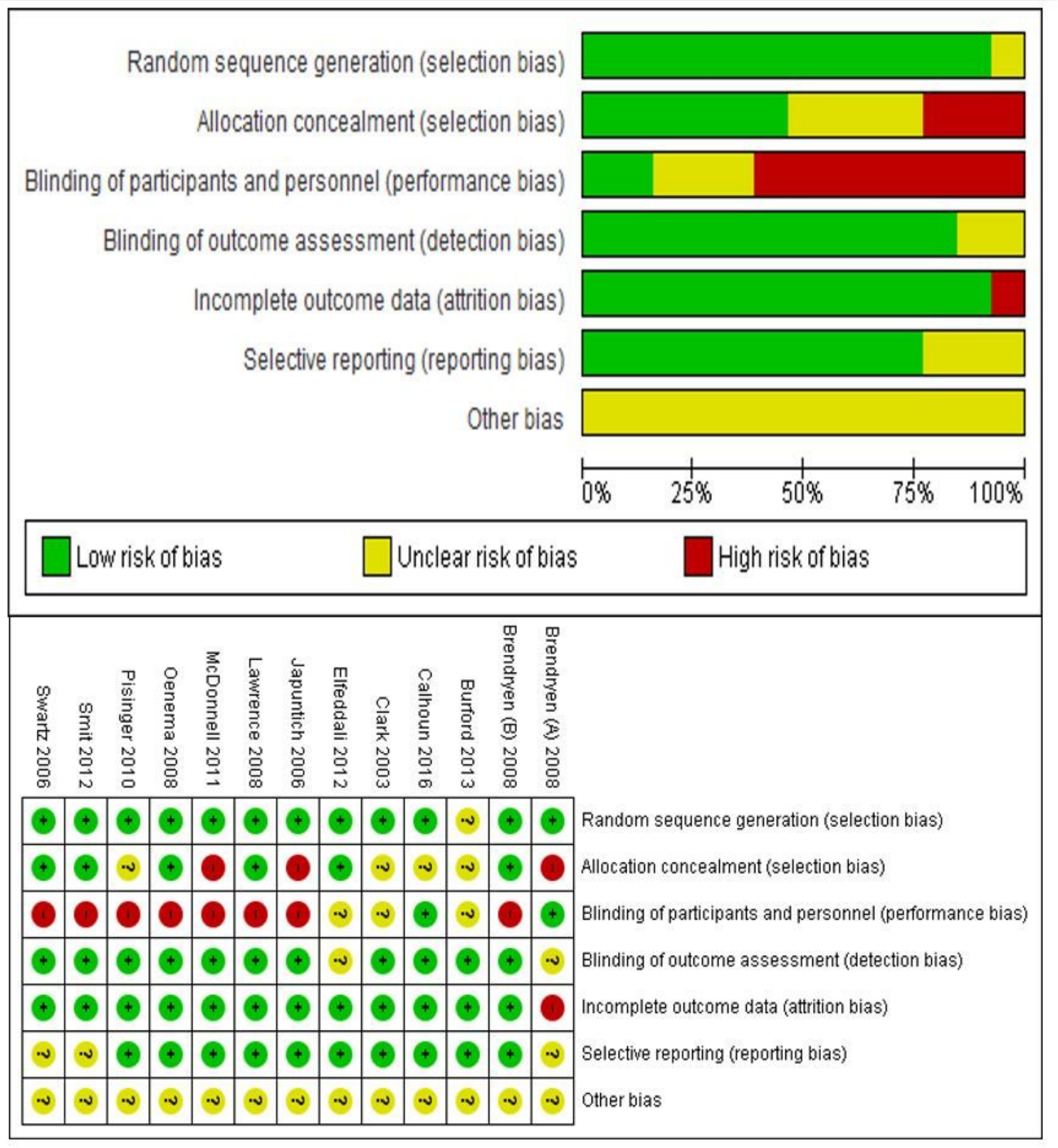

\section{Figure 2}

Risk of bias graph and summary 


\begin{tabular}{|c|c|c|c|c|c|c|c|c|}
\hline Study or Subgroup & \multicolumn{2}{|c|}{ Intervention } & \multicolumn{2}{|c|}{ Control } & Weight & $\begin{array}{l}\text { Odds Ratio } \\
\text { M-H, Fixed, } 95 \% \mathrm{Cl}\end{array}$ & $\begin{array}{l}\text { Odds Ratio } \\
\text { M-H, Fixed, } 95 \% \mathrm{Cl}\end{array}$ & $\begin{array}{l}\text { Ratio } \\
\text { d, } 95 \% \mathrm{Cl}\end{array}$ \\
\hline Brendryen (A) 2008 & 99 & 200 & 59 & 200 & $33.9 \%$ & $2.34[1.55,3.53]$ & & $=$ \\
\hline Brendryen (B) 2008 & 60 & 144 & 25 & 146 & $16.5 \%$ & $3.46[2.01,5.95]$ & & 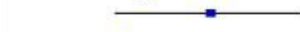 \\
\hline Clark 2003 & 8 & 85 & 4 & 86 & $4.1 \%$ & $2.13[0.62,7.36]$ & & \\
\hline Smit 2012 & 74 & 552 & 38 & 571 & $36.8 \%$ & $2.17[1.44,3.27]$ & & \\
\hline Total $(95 \% \mathrm{CI})$ & & 1253 & & 1278 & $100.0 \%$ & $2.37[1.86,3.02]$ & & \\
\hline Total events & 252 & & 134 & & & & & \\
\hline $\begin{array}{l}\text { Heterogeneity: Chi" = } \\
\text { Test for overall effect: }\end{array}$ & $\begin{array}{l}3.28, \mathrm{df}= \\
=7.01\end{array}$ & $\begin{array}{l}(P=0 \\
<0.00\end{array}$ & $\begin{array}{l}\text { 51); } 1^{2}= \\
001)\end{array}$ & $0 \%$ & & & 0.2 Favours [Control] ${ }^{1}$ & $\begin{array}{cc}2 & \frac{1}{2} \\
\text { Favours [Intervention] }\end{array}$ \\
\hline
\end{tabular}

\section{Tobacco quit at 3 months follow up}

\begin{tabular}{|c|c|c|c|c|c|}
\hline \multirow[b]{2}{*}{ Study or Subgroup } & \multicolumn{2}{|c|}{ Intervention } & \multicolumn{2}{|c|}{ Control } & \multirow[b]{2}{*}{ Weight } \\
\hline & Events & Total & Events & Total & \\
\hline Brendryen (A) 2008 & 88 & 200 & 57 & 200 & $32.8 \%$ \\
\hline Brendryen (B) 2008 & 51 & 144 & 23 & 146 & $15.2 \%$ \\
\hline Calhoun 2016 & 35 & 205 & 24 & 203 & $20.6 \%$ \\
\hline Japuntich 2006 & 32 & 140 & 30 & 144 & $23.5 \%$ \\
\hline Swartz 2006 & 21 & 171 & 9 & 180 & $7.9 \%$ \\
\hline Total $(95 \% \mathrm{CI})$ & & 860 & & 873 & $100.0 \%$ \\
\hline Total events & 227 & & 143 & & \\
\hline
\end{tabular}

Odds Ratio -H, Fixed, $95 \% \mathrm{Cl}$ $1.97[1.30,2.99]$ $2.93[1.67,5.14]$ $1.54[0.88,2.69]$ $1.13[0.64,1.98]$ $2.66[1.18,5.99]$

$1.88[1.48,2.40]$

Test for overall effect: $Z=5.14(P<0.00001)$

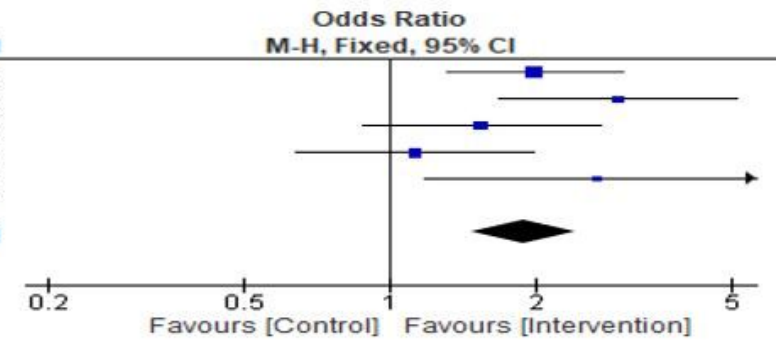

Tobacco quit at 6 months follow up

Intervention Control

\begin{tabular}{lrrrrr} 
Study or Subgroup & Events & Total & Events & Total & Weight \\
\hline Brendryen (A) 2008 & 73 & 200 & 43 & 200 & $22.3 \%$ \\
Brendryen (B) 2008 & 42 & 144 & 20 & 146 & $11.5 \%$ \\
Burford 2013 & 11 & 80 & 1 & 80 & $0.7 \%$ \\
Japuntich 2006 & 21 & 140 & 17 & 144 & $11.6 \%$ \\
Lawrence 2008 & 105 & 257 & 60 & 260 & $28.8 \%$ \\
Smit 2012 & 45 & 552 & 34 & 571 & $25.1 \%$ \\
Total (95\% CI) & \multicolumn{7}{c}{1373} & & 1401 & $100.0 \%$ \\
Total events & 297 & 175 \\
Heterogeneity: Chi $=8.06$, df $=5(P=0.15) ; I^{2}=38 \%$ \\
Test for overall effect: $Z=6.52(P<0.00001)$
\end{tabular}

Odds Ratio

M-H, Fixed, 95\% Cl $2.10[1.35,3.27]$ $2.59[1.43,4.69]$ $12.59[1.59,100.05]$ $1.32[0.66,2.62]$

$2.30[1.57,3.37]$

$1.40[0.88,2.22]$

$2.02[1.64,2.50]$

Test for overall effect: $Z=6.52(P<0.00001)$

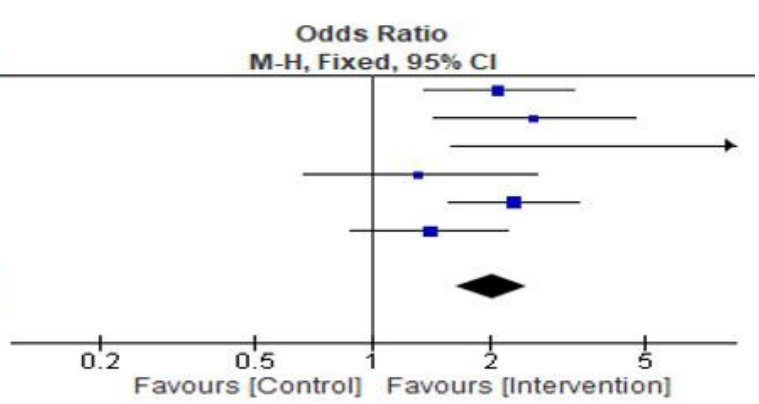

\section{Tobacco quit at one year follow up}

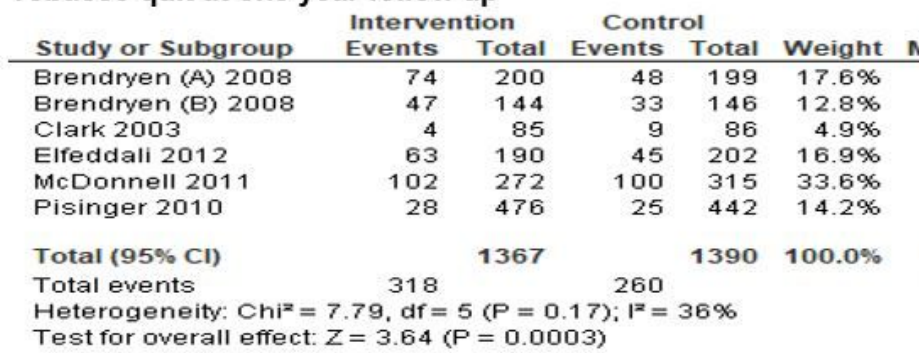

Odds Ratio

-H, Fixed, $95 \% \mathrm{Cl}$

$1.85[1.20,2.85]$

$1.66[0.99,2.79]$

$0.42[0.12,1.43]$

$1.73[1.11,2.71]$

$1.29[0.92,1.81]$

$1.04[0.60,1.82]$

$1.43[1.18,1.74]$
Odds Ratio

\begin{tabular}{c|c|}
\hline \multicolumn{2}{c}{ M-H, Fixed, $95 \% \mathrm{Cl}$} \\
\cline { 2 - 3 } \\
\hline
\end{tabular}

Figure 3

Forest plot comparing internet intervention with the control group 
a)

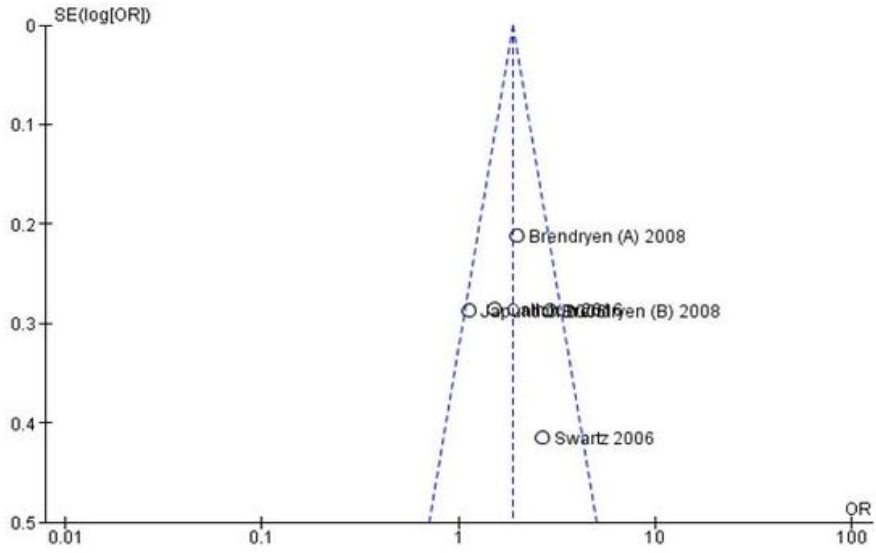

c)

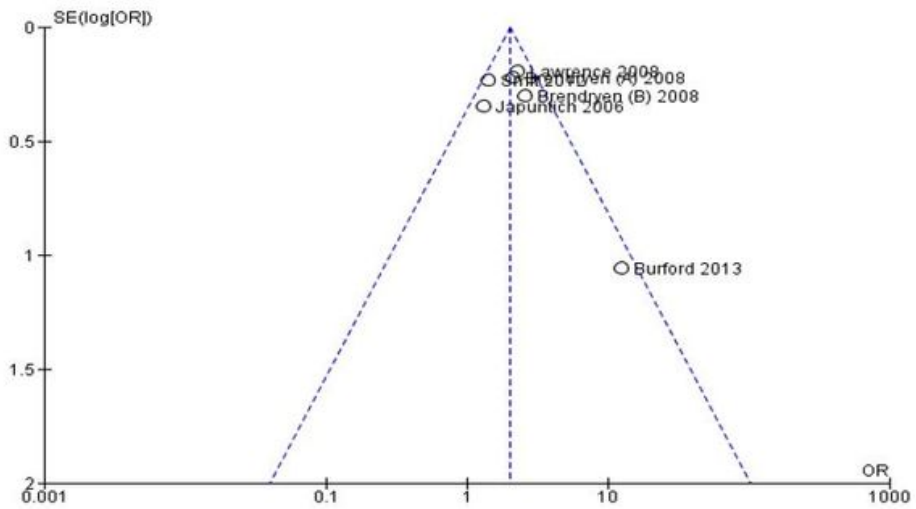

b)

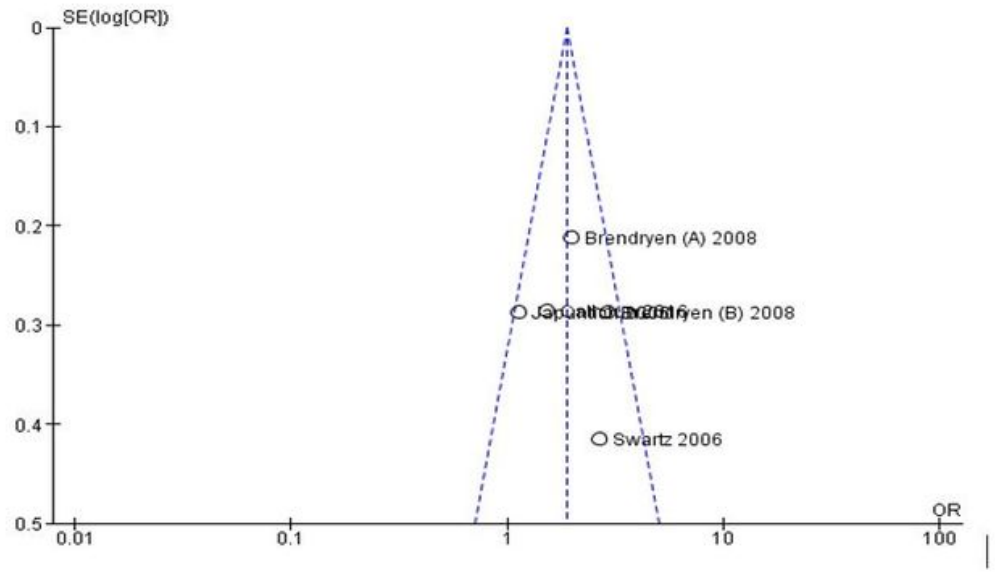

d)

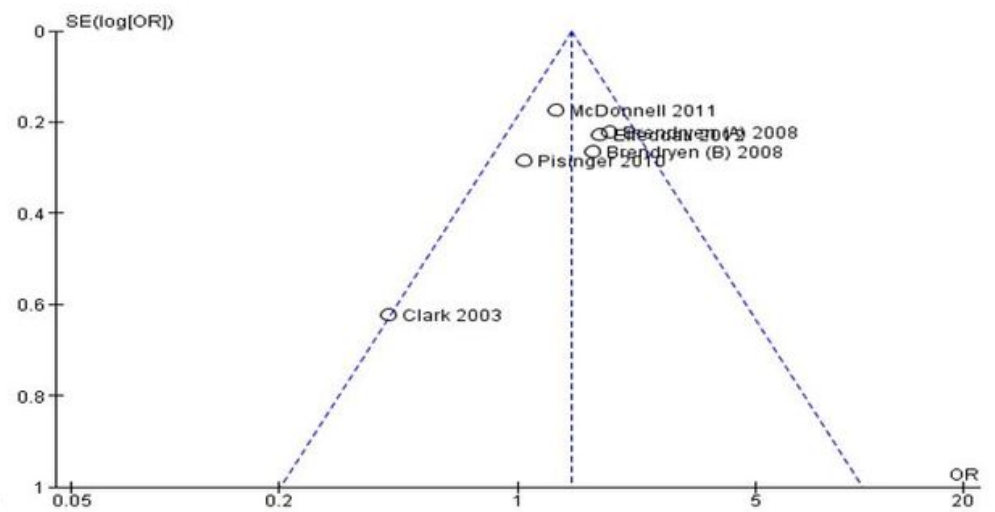

Figure 4

Funnel plot: shows publication bias across studies for each outcome. a) Tobacco quitting at one month b) Tobacco quitting at three months c) Tobacco quitting at six months d) Tobacco quitting at one year 